\title{
Equality Before the Law for Male and Female Worker at PT Perkebunan Nusantara III (PTPN III)
}

\author{
C O Perangin angin ${ }^{1}$ and B Nasution ${ }^{2}$ \\ Law Program, Universitas Sumatra Utara, Medan, Indonesia \\ ${ }^{1}$ orchard27christian@gmail.com
}

\begin{abstract}
This study discusses the equality before the law for male and female worker at PTPN III. Ideally, human relation must be established without discrimination. This study focuses on finding out the causes of why PTPN III did not apply equality before the law to male and female workers. This is a normative legal research using a normative juridical method. There is an imbalance of the human relation among the workers since the company does not apply the principle of equality before the law. In the context of remuneration, the provisions of Article 44 Paragraph (1) and (4) of the Collective Labor Agreement for the year of 20162017 between PTPN III and the Worker Union of PTPN III (CLA) contain a discrimination against women workers. Legal protection for women workers from discrimination has been regulated in the 1945 Constitution, various laws and regulations, and ILO conventions. In conclusion, discrimination of workers is contrary to the human rights. The CLA should immediately be revised to achieve the equality before the law for male and female workers.
\end{abstract}

Keywords: PTPN III, Worker, Discrimination

\section{INTRODUCTION}

According to Article 27 Paragraph (1) of the 1945 Constitution, everyone shall be equal before the law and shall uphold the law with no exceptions and has the right to work and to have an appropriate live.Until now a number of state-owned enterprises (SOE) continue running their business activities [1], and one of which is PT Perkebunan Nusantara III (PTPN III). In carrying out its business activities, PTPN III certainly cannot be separated from the workers.

According to Article 1 Paragraph (2) and (3) of Law Number 13 of 2003, workers are certainly not limited to male workers, but also female workers. These provisions should also be applicable for workers at PTPN III. In fact, in the working relationships at PTPN III, the greater wage of male workers than that of female workers is certainly discrimination, and is obviously contrary to the provisions of Article 27 (1) of the 1945 Constitution (UUD), and Article 4 of Law Number 39 of 1999 on Human Rights (UUHAM).

In addition, the number of female workers at PTPN III decreases every year because male workers are more preferable than female workers. Certainly, this fact is also another discrimination against female workers. 
The problem of this research is formulated into the following question: How does the equality before the law principle apply for female workers at PTPN III?

\section{METHODS}

This study was a normative legal research using a normative juridical approach as the method. The data were collected through a library research, i.e. reading documents, literature and provisions of legislation related to the research problem. All the collected data were then reviewed and analyzed qualitatively. Then the data were re-described to be presented systematically, resulting in a discussion that could be used to answer the formulated problem.

\section{RESULT and DISCUSSION}

According to Asshiddiqie, the principle of a state of law is constantly revolving on two main issues, namely the limitation of power and the protection of human rights [2]. One of the main principles which becomes the main pillar of a state of law is a principle of equality before the law in which each person shall be equal before the law and shall uphold the law with no exception.

Based on the provisions of Article 27 (1) of the 1945 Constitution and Article 4 of law on Human Rights, the principle of equality before the law is one of the main principles serving as the main pillar of a state of law.Thus ideally, the salary of male and female workers at PTPN III must be equal (there must be no discrimination).

In fact, there is a discrimination of worker remuneration where the wages of male workers are greater than that of female. This discrimination is derived from the provisions of Article 44 Paragraph (1) of Collective Labor Agreement for the 2016-2017 between PTPN III and Workers Union (SPBUN) of PTPN III (Abbreviated as CLA) which has been recorded in the Office of Manpower and Transmigration of the Government of North Sumatra Province.

It has been affirmed that such discrimination appears because, based on Article 44 CLA, there are 3 (three) criteria for female workers to be treated as head of the family (so their wages can be equally similar to male workers).

First, the female worker shall be a widow with a child due to her husband's death. Second, her husband is unable to earn a living due to his physical and/or spiritual conditions which must be proved by the doctor's medical certificate. Third, she is a widow due to a divorce, and her children become her dependents based on a verdict of a court/valid certificate.

If any of the three criteria isfulfilled, the female workers are considered as the head of the family, and are entitled to receive wages, allowances, social benefits, and other legal receipts as applicable to other married workers.

Based on Article 44 Paragraph (4) CLA, the female workers who remarry lose their status as the head of the family. Referring to the Human Rights Law, the provisions of Paragraph (4) of the CLA are obviously contrary to the provisions of Article 10 (1) of the Human Rights Law.

The discrimination of remuneration for male and female workers at PTPN III illustrates that the Government has not been able to maximally provide a legal protection for the female workers.

The Indonesian government has ratified the Convention on the Elimination of All Forms of Discrimination Against Women through Law Number 7 of 1984 concerning the Ratification of the Convention on the Elimination of Discrimination against Women on July 24, 1984. 
Previously, Indonesia has also ratified several International Charter and Conventions relating to the equal rights of women and men. They are the United Nations Charter, the Convention relating to the payment of male and female workers for equal work load (ILO Convention No. 100), the Convention on women's political rights (Law Number 18 of 1956) and others [3].

The culture and the religious teachings in Indonesia are still reluctant to recognize the equality of men and women. Tragically, this attitude was later adopted to be the official attitude of the state. Elucidation of Law Number 7 of 1984 states that the provisions in this convention must be adjusted to the social order of the society covering the cultural values, customs and religious norms that are still valid and widely followed by the people of Indonesia.

Ministerial Regulation Number SE-04 / Men / 1988 which was issued with reference to Law No. 7 of 1984 turned out to be contrary to the principles contained in the Women's Convention. The Ministerial Regulation concerning the implementation of the prohibition on discrimination of women workers, among others, regulates health care insurance, which states that both male and female workers receive similar health benefits unless the female worker has received health benefits from her husband, both from the same company and from different companies [3].This means that if a female worker has received a medical allowance from her husband, then she is considered to be unmarried, so she loses her right to obtain the same allowance as her male partner.

This policy is clearly very discriminative and contradicts the main point contained in the Women's Convention in conjunction with Law No. 7 of 1984 which actually became the basis for the issuance of the Ministerial Regulation. It is clearly stated that the official view of the government towards women is still seen as a wife/mother and therefore her status is always associated with her husband. A woman may be a wife or mother, but she remains as an individual with autonomy, a citizen who has rights that are as important as other citizens at home, at work or in other public sectors. She is a human being of the same degree as any other human being whether he is her husband, her father, her son or her male colleagues [4].

This Ministerial Regulation is adopted and becomes a reference in the provisions of Article 44 Paragraph (1) and (4) of the CLA. The provision that determines the criteria for female workers to be treated as a head of a family, and that those who remarry will lose their status as a head of a family is obviously contrary to the 1945 Constitution and the Human Rights Law.

Rawls' theory of justice in relation to the principle of equality states that everyone should have equal rights to gain the greatest freedom under a system of freedom which gives equal opportunity to all people. According to Rawls, dissimilarity or inequality in the socioeconomic field must be regulated thoroughly so that the weakest are the most beneficiaries, and everyone is given an equal opportunity [5].

However, based on legal analysis, gender differences cannot serve as a justification for preference to male workers in the recruitment process at PTPN III because, in addition to cause discrimination that creates injustice for female workers, such preference is also obviously contrary to the Constitution, Human Rights Law and various ILO Conventions.

In order to protect PTPN III female workerrights that have been harmed due to a discrimination, and in order to make future female workers utilize their rights given by the law, the Government through the relevant ministries must carry out their obligations and responsibilities in law enforcement and human rights enforcement, as set forth in Article 71 and Article 72 of Human Right law.

Efforts that can be implemented by the Government are; (i)ordering PTPN III to immediately revise the provisions of Article 44 of the CLA; and, (ii) ordering PTPN III not to 
discriminate the process of worker recruitment on the basis of gender.Implementing the two efforts above will hopefully dismiss discrimination of worker at PTPN III, which automatically realizes the equality before the law, justice, legal protection, legal certainty and utility.

\section{CONCLUSION}

Not implementing the equality before the law for female workers at PTPN III is mainly caused by the provisions of Article 44 Paragraph (1) and (4) of the CLA which determine the criteria for female workers to be a head of a family and to lose their status as a head of a family after remarried. As a result, such collective labor agreement has not been enforceable as a law for the binding parties.

The main cause of male worker preference in the recruitment process at PTPN III is an assumption that male workers work more effectively than do female workers. Such assumption cannot be legally used as a justification for PTPN III because it is clearly a form of discrimination leading to injustice for female workers. In addition, it also obviously contradictsthe provisions of Article 27 Paragraph (1) and (2), Article 28D Paragraph (1)and (2) of the 1945 Constitution, Article 4 of Human Right Lawand various ILO Conventions relating to female worker discrimation. Finally, it is really recommended to order PTPN III to immediately revise the provisions of Article 44 of the CLA.

\section{REFERENCES}

[1] D. Nasution and N. N. Sirait, "Urgency of Local-Owned Enterprises (BUMD) Law as Good Corporate Governance Basis in Indonesia," in Proceedings of the International Conference on Public Policy, Social Computing and Development 2017 (ICOPOSDev 2017), 2018.

[2] J. Asshiddiqie, Hukum Tata Negara dan Pilar-Pilar Demokrasi. Jakarta: Sinar Grafika, 2012.

[3] A. Wijayanti, Sinkronisasi Hukum Perburuhan Terhadap Konvensi ILO: Analisis Kebebasan Berserikat dan Penghapusan Kerja Paksa di Indonesia. Bandung: Penerbit CV. Karya Putra Darwati, 2012.

[4] S. Rahima, "Perempuan Bekerja, Dilemma Tak Berujung," Swara Rahima Media Islam untuk Hak-Hak Peremp., vol. 4, no. 12, 2004.

[5] J. Rawls, A Theory of Justice. Cambrige: The Belknap Press of Harvard University Press, 1971. 